\title{
3-Acetyl-11-keto- $\beta$-boswellic acid inhibits cancer cell invasion and induces apoptosis in breast cancer cells by abrogating the EGFR-mediated PI3K/Akt pathway
}

\author{
Ruishan Zhang, Hong Xu, Xiang Li, Zhuangkai Liu, Yuying Wang, Zhao Zhao
}

Department of Breast Cancer, Cancer Hospital of China Medical University, Liaoning Cancer Hospital and Institute, Dadong District, Shenyang, Liaoning, China

Submitted: 4 January 2020

Accepted: 1 April 2020

Arch Med Sci

DOI: https://doi.org/10.5114/aoms.2020.95421

Copyright $\odot 2020$ Termedia \& Banach

\section{Abstract}

Introduction: Recent evidence has demonstrated the anticancer potential of 3 -acetyl-11-keto- $\beta$-boswellic acid (AKBA). The current study was performed to evaluate the anti-invasive and antimotility effect of AKBA against breast cancer (BC) cells.

Material and methods: The antiproliferative assay was used to evaluate cell viability. Wound healing assay and Transwell invasion assay were used for migration and invasion respectively. Annexin V FITC assay and microscopy were used to quantify and detect apoptosis. Zymography and immunoblotting analysis were used for gelatinase activity of matrix metalloproteinases (MMPs) and protein expression of signaling proteins involved in apoptosis, tumor cell invasion and motility of BC cells.

Results: AKBA exhibits significant inhibition of cell proliferation and suppresses BC cell motility. Mechanistically, AKBA suppresses migration and invasion, and attenuates MMP-2 and MMP-9 activity, which plays a key role in metastasis. Furthermore, a dose-dependent manner of AKBA promotes significant induction of apoptosis. Moreover, we observed that a higher concentration of AKBA reduces phosphorylation of EGFR, PI3K, and Akt with a subsequent decrease in MMP-9 and MMP-2 expression, and an increase in TIMP1 and E-cadherin expression. However, pre-treatment with EGF in BC cells restores significant cell motility and invasion even in the presence of $A K B A$, indicating that inhibition of cell migration by AKBA is operated by the EGFR/PI3K/Akt axis. Additionally, AKBA showed a significant inhibitory and strong synergistic effect on EGFR-mediated PI3K/Akt signaling associated proteins when compared with the known inhibitors gefitinib and erlotinib. Conclusions: AKBA exhibits potential antiproliferative effects by inducing apoptosis and suppresses tumor cell motility and invasion, which is mediated by the EGFR/PI3K/Akt axis in BC cells.

Key words: boswellic acid, apoptosis, invasions, breast cancer, EGFR.

\section{Introduction}

Despite the advances in awareness and therapeutics, breast cancer remains a top-ranked malignancy in terms of mortality in the USA. Breast cancer incidence is increasing alarmingly and is expected to rise in the future [1]. One of the prime causes is the late planning of pregnancy and then a reduction in breastfeeding duration, stimulating a trigger in the pathogenesis of breast cancer [2, 3]. Owing to having few symptomatic

\author{
Corresponding author: \\ Hong Xu PhD \\ Department of \\ Breast Cancer \\ Cancer Hospital of \\ China Medical University \\ Liaoning Cancer Hospital \\ and Institute \\ 44 Xiaoheyan Road \\ Dadong District \\ Shenyang \\ Liaoning 110042, China \\ E-mail: HanaBeckerpia@ \\ yahoo.com
}


manifestations, breast cancer is very hard to detect in the early stages of the disease and hence commonly diagnosed during advanced stages of the disease. Despite significant improvement in diagnostic and therapeutic strategies, the outcome of breast cancer therapeutics is dismal because of challenges such as advanced stage metastasis, drug resistance, and adverse side effects [2]. The resistance developed against radiotherapy in almost half of the advanced breast cancer patients is due to the hypoxia created deep inside the tumor microenvironment $[4,5]$. However, breast cancer heterogeneity is another major factor against the target-specific chemotherapeutics $[4,6,7]$. Based on the gene expression profile breast cancer cells have five different subtypes: normal-like, basal-like, HER-2 positive, luminal type $A$ and luminal type B. Intriguingly, the medical outcome varies within each subtype [8]; e.g. luminal type $A$ and luminal type $B$ represent MCF-7 and BT-474 cells respectively, are androgen receptor (ER)-positive and respond to hormone therapy. However, MCF-7 is negative for HER2 whereas BT-474 is positive for HER2 $[9,10]$. Additionally, luminal A subtype is markedly differentiated and this type of breast cancer has a good prognosis, whereas highly proliferative cells of luminal B type have a poor prognosis $[11,12]$. Therefore, a multiple target therapeutic strategy, which not only kills cancer cells but also makes inroads in tumor cell metastasis and has less toxic effects on normal cells, is needed.

Owing to low toxicity effects on normal cells, natural compounds are novel, complex structures and can modulate the heterogeneous group of cancer cells by targeting multiple signaling pathways [13]. Numerous studies have demonstrated that phytochemicals have promising antitumor potential against BC; e.g., resveratrol, withaferin A, sulforaphane and curcumin-induced apoptosis mediated cell killing, arrest cell cycle and decrease proliferation of BC cells [14-18]. Moreover, recently various reports have shown that natural compounds not only induce apoptosis in cancer cells but can modulate tumor cell invasion and make inroads in BC metastasis [19]. Thus, natural compounds are considered an attractive agent for comprehensive therapeutics of BC.

AKBA is a key component of gum resin obtained from the plant Boswellia serrata. The Indian traditional Ayurveda system of medicine has long been using AKBA to treat various inflammatory ailments which include ulcerative colitis, bronchial asthma, chronic colitis, Crohn's disease and osteoarthritis [20, 21]. Recently, AKBA has been shown to exhibit an anti-tumor effect to activate apoptotic mechanisms in numerous types of malignancies such as prostate cancer, pancreatic cancer, glioblastoma, colon cancer, hepatoma and fibrosarcoma [22-26]. However, whether AKBA could modulate tumor cell motility and invasion in $B C$ cells, the underlying mechanisms are still not clear.

Therefore, the current study aims to evaluate and investigate the anti-tumor mechanism induced by AKBA in subtypes luminal $A$ and $B$ cell lines (MCF-7 and BT-474). The current study is the first report to reveal that AKBA exhibits significant antiproliferative potential and simultaneously suppresses migration and cell invasion by decreasing expression as well as activity of MMP-2/9 and potentiates apoptosis in both subtypes luminal $A$ and $B$ cell lines. We also found that AKBA reduces the phosphorylation of EGFR and abrogates $\mathrm{PI3K} /$ Akt signaling pathway by suppressing MMP2/9 expression and upregulates E-cadherin and TIMP1 expression in BC cells. Collectively these results demonstrate that $A K B A$ could be a promising chemotherapeutic natural compound in the therapeutics of BC.

\section{Material and methods}

\section{Culturing of cells and their treatments}

BC cells (MCF-7, BT-474) and the MCF-10 transformed normal cell line were procured from American Type Culture Collection (ATCC) and were maintained, cultured in Dulbecco's Modified Essential Medium (DMEM) (\#A4192101) containing 10\% fetal bovine serum (FBS) (\#16000044), penicillin-streptomycin solution (\#15140130), in a humidified incubator with $5 \% \mathrm{CO}_{2}$. All the cell lines were free from Mycoplasma contamination.

\section{Preparation of AKBA dilutions}

$20 \mathrm{mg} / \mathrm{ml}$ stock solution of AKBA was prepared in dimethyl sulfoxide (DMSO). Aliquots of stock solutions were prepared and stored at $-20^{\circ} \mathrm{C}$. Further, the dilution of stock solution was done in DMEM to prepare a working solution of desired concentrations between 10 and $40 \mu \mathrm{M}$ for the treatment of cultured cells.

\section{Chemicals, reagents, and antibodies}

AKBA (\#A9855), gelatin (\#G1890), 3-(4, 5-dimethylthiazol-2-y1)-2, 5-diphenyltetrazolium bromide (MTT) (\#M5655), Brij-35 (\#203728), propidium iodide (PI) (\#P4170), Coomassie Brilliant Blue (R-250) (\#1125530025), phenylmethylsulfonyl fluoride (PMSF) (\#78830), dithiothreitol (DTT) (\#10197777001), DMSO (\#C6164), Bradford reagent (\#B6916), Annexin V and FITC kit for the detection of apoptosis (\#APOAF), gefitinib (\#SML1657), erlotinib (\#SML2156) and protease inhibitor cocktail (\#P8340), were purchased from Sigma-Aldrich. Cell Signaling Technology anti- 
bodies procured for the current study were: $\beta$-actin (\#3700S, 1 : 10000 dilution), EGFR (\#4267S, 1 : 1000 dilution), p-EGFR-Tyr1173 (\#2244S, 1 : 1000 dilution), PARP1 (\#9532S, 1 : 1000 dilution), PI3K-p110a (\#4255S, 1 : 1000 dilution), caspase-3 (\#9662S, 1 : 1000 dilution), Akt (\#4685S, 1 : 1000 dilution), p-Akt-Ser473 (\#4060S, 1 : 1000 dilution), MMP-9 (\#13667S, 1 : 1000 dilution), MMP-2 (\#40994S, $1: 1000 \mathrm{di}-$ lution), E-cadherin (\#14472S, $1: 2000$ dilution), and TIMP1 (\#8946S, 1 : 1000 dilution). Secondary anti-mouse IgG-coupled (\#sc-2005, 1 : 2000 dilution) and anti-rabbit coupled (\#sc-2357, $1: 2000$ dilution) with horseradish peroxidase (HRP) were purchased from Santa Cruz Biotechnology.

\section{Cell viability assay}

The proliferation of cells was analyzed by MTT assay as per the standard protocol [27]. Briefly, BC cells (MCF-7, BT-474) along with the transformed normal (MCF-10A) cells were plated at a density of $5 \times 10^{3}$ cells per well of a 96-well plate. The cells were treated with varying concentrations of AKBA (0.2-200 $\mu \mathrm{M})$ and control DMSO for $24 \mathrm{~h}$ in an incubator containing $5 \% \mathrm{CO}_{2}$. Subsequently, cells were incubated with MTT dye $(2.5 \mathrm{mg} / \mathrm{ml})$ for $3 \mathrm{~h}$ at $37^{\circ} \mathrm{C}$. The formazan crystals formed were solubilized in DMSO, mixed properly by vortex and absorbance was measured at $570 \mathrm{~nm}$ by a multiplate reader. The percentage of cell proliferation was analyzed as the percent cell viability of treated cells compared with the control DMSO cells.

\section{Detection of apoptosis}

BC cells were seeded at a density of $0.5 \times 10^{6}$ cells per well in a 6 -well plate and treated with different concentrations $(20,30,40 \mu \mathrm{M})$ of AKBA along with control DMSO. After $24 \mathrm{~h}$, cells were harvested with a cell scraper, processed and incubated with annexin $\mathrm{V}$ and $\mathrm{PI}$ as directed in the protocol. After completion of the staining process, cells were analyzed by flow cytometry to quantify the apoptotic cell population.

\section{Scratch motility (wound healing) assay}

Briefly, BC cells (MCF-7 and BT-474) were plated at a density of $5.5 \times 10^{5}$ cells per well of a 6 -well plate and allowed to adhere to make a complete monolayer for $24 \mathrm{~h}$. The monolayer formed was scratched with a sterile micropipette tip $(200 \mu \mathrm{l})$ to create a wound and was gently washed with serum-free medium to wash out detached cells. Photographs were taken at the time of creating wound $(0 \mathrm{~h})$. Cells were incubated in low-serum medium (1\%) and simultaneously exposed to varying concentrations of AKBA $(10,20,30 \mu \mathrm{M})$ along with control DMSO for $24 \mathrm{~h}$. The photo- graphs were taken with an inbuilt camera of the microscope from the areas where wounds were created at $0 \mathrm{~h}$. The closure of the wound was determined as a percentage by using the formula: Closure wound \% age $=[1-($ area of wound after $24 \mathrm{~h} /$ area of wound at $0 \mathrm{~h}$ ) $\times 100 \%]$.

\section{Gelatin zymography}

BC cells (MCF-7 and BT-474) at a density of $0.5 \times 10^{6}$ were seeded in a 6-well plate and allowed to adhere to the surface overnight. Cells were exposed to varying concentrations $(10,20$, $30 \mu \mathrm{M})$ of AKBA along with control DMSO for $24 \mathrm{~h}$. The conditional medium was collected from the cells exposed to varying concentrations of AKBA along with control untreated cells, after the completion of the time. Conditional medium samples were subjected to protein estimation and an equal quantity of protein was mixed with sample loading dye (25\% glycerol, 2.0\% SDS, 60 mM Tris$\mathrm{HCl}, 0.1 \%$ bromophenol blue and $\mathrm{pH}$ 6.8). Gelatin zymography was performed with SDS-polyacrylamide gels having composition $7.5 \%$, gelatin $0.1 \%$, running at $4^{\circ} \mathrm{C}$ for $3 \mathrm{~h}$ at $100 \mathrm{~V}$. After resolving the gel completely under a given condition of temperature and voltage, the gel was washed at room temperature with buffer containing $2 \mathrm{ml}$ of Triton X-100 in $98 \mathrm{ml}$ of double-distilled water, to wash out SDS. The gel was then incubated for $24 \mathrm{~h}$ at $37^{\circ} \mathrm{C}$ in incubation buffer $\left(0.02 \% \mathrm{NaN}_{3}\right.$, $10 \mathrm{mM} \mathrm{CaCl}_{2}, 50 \mathrm{mM}$ Tris- $\mathrm{HCl}, \mathrm{pH}$ 8.0) and stained for $1-1.5 \mathrm{~h}$ in Coomassie staining solution followed by destaining with a destaining solution. Detection of gelatinase activity was analyzed by spotting stainless bands on a dark blue background on a gel stained with Coomassie brilliant blue.

\section{Matrigel invasion assay}

To evaluate the anti-invasive potential of AKBA, Transwell Boyden chamber plates obtained from BD Bioscience were used. Briefly, BC cells (1.25 x $10^{6}$ ) were seeded, incubated and exposed to varying concentrations of AKBA $(10,20,30 \mu \mathrm{M})$ along with control DMSO for $24 \mathrm{~h}$ in serum-free medium in the upper chamber and the lower chamber was filled with $10 \%$ complete medium as a chemoattractant. After $24 \mathrm{~h}$, the Matrigel-coated polycarbonate biological porous membrane inserts were removed and the cells attached from the upper side of the chamber were scraped completely with a swab of cotton. The porous inserts containing cells from the lower chamber side were fixed in ice-cold methanol for $10 \mathrm{~min}$ and stained by dipping the inserts in $0.1 \%$ crystal violet solution. The migration of the cells was analyzed by taking photographs of the bottom side of the attached 
migrated cells and the migrated stained cells were counted under the phase-contrast microscope.

\section{Phase-contrast microscopy}

BC cells $\left(5 \times 10^{4}\right)$ were cultured on coverslips with varying $(20,30,40 \mu \mathrm{M})$ concentrations of AKBA along with control DMSO for $24 \mathrm{~h}$ to analyze the changes in the cellular morphology. Cells were processed for the phase-contrast microscope to analyze the morphological changes in treated cells.

\section{Immunoblotting}

After overnight plating of $50 \times 10^{5}$ cells/well in a humidified $5 \% \mathrm{CO}_{2}$ incubator at $37^{\circ} \mathrm{C}, \mathrm{BC}$ cells were exposed to varying concentrations $(20,30$, $40 \mu \mathrm{M})$ of AKBA along with control DMSO. After $24 \mathrm{~h}$, cells were harvested and washed with icecold PBS. The cells were lysed and processed at $4^{\circ} \mathrm{C}$ for centrifugation at a speed of $13000 \mathrm{~g}$ for 10 min. Supernatants collected from centrifugation in a separate tube were subjected to the Bradford method of protein estimation. Then $20 \mu \mathrm{g}$ of protein from each treated sample was loaded in the wells of SDS-PAGE gel. After resolving properly, SDS-PAGE gel was subjected to transfer onto the PVDF membrane, and incubated in fat-free milk (5\%) blocking solution dissolved in TBST. After blocking nonspecific proteins, the PVDF membrane was incubated and probed with the desired antibodies (1:1000 dilutions) for at least 3-4 $\mathrm{h}$ at room temperature or $4^{\circ} \mathrm{C}$ overnight. The PVDF membrane was washed with TBST buffer three times. The pre-incubated membrane with primary antibody was probed with horseradish peroxidase-labeled secondary antibody for at least $1 \mathrm{~h}$. After washing three times with TBST buffer, immunosubstance proteins were visualized using ECL Plus on the PVDF membrane.

\section{A}

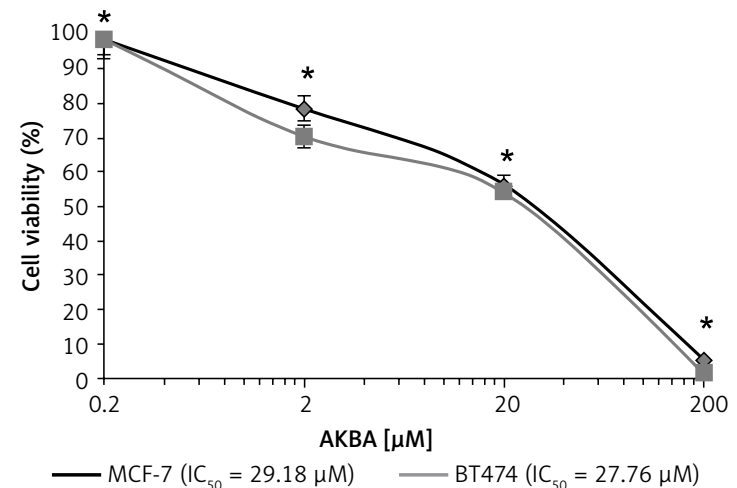

\section{Statistical analysis}

All the evaluated experiments were performed three or more independent times. The latest version of the software GraphPad Prism was used for statistical analysis of all independent unbiased experiments. The results obtained were presented as the mean \pm SEM. Entire results were calculated using Student's unpaired $t$-test, wherein a $p$-value not more than 0.05 was considered significant $\left({ }^{*} p<0.05,{ }^{* *} p<0.01\right.$, and $\left.{ }^{* * *} p<0.001\right)$.

\section{Results}

\section{AKBA exhibits a promising antiproliferative effect on $B C$ cells}

Previous reports demonstrated that AKBA exhibits a antiproliferative effect on various tumor cell models. Hence, we wanted to inspect the in vitro inhibitory activity of AKBA on the growth of luminal $A$ and $B$ subtype cells. AKBA inhibits $B C$ cells in a concentration-dependent manner. The MTT assay was performed to evaluate the inhibitory effect on cell viability. Our results revealed that AKBA initiated an antiproliferative effect on both the types of BC cells (MCF-7 and BT-474) at a concentration of $10 \mu \mathrm{M}$. However, when the $I C_{50}$ concentration values of AKBA was calculated by GraphPad Prism software, we found that the $I C_{50}$ value was $29.18 \mu \mathrm{M}$ and $27.76 \mu \mathrm{M}$ for MCF-7 and BT-474 BC cells respectively (Figure $1 \mathrm{~A}$ ). Interestingly, when the antiproliferative effect was evaluated for transformed normal MCF-10A cells, we found that $50 \%$ of the population of cells were killed at $112.45 \mu \mathrm{M}$ of AKBA (Figure $1 \mathrm{~B}$ ), which is quite a high concentration compared to the $I C_{50}$ value of $B C$ cells, indicating that AKBA specifically inhibits the growth of cancer cells and displays a safe toxicity profile on normal cells. Collectively, these results revealed that AKBA exhibits a prom-
B

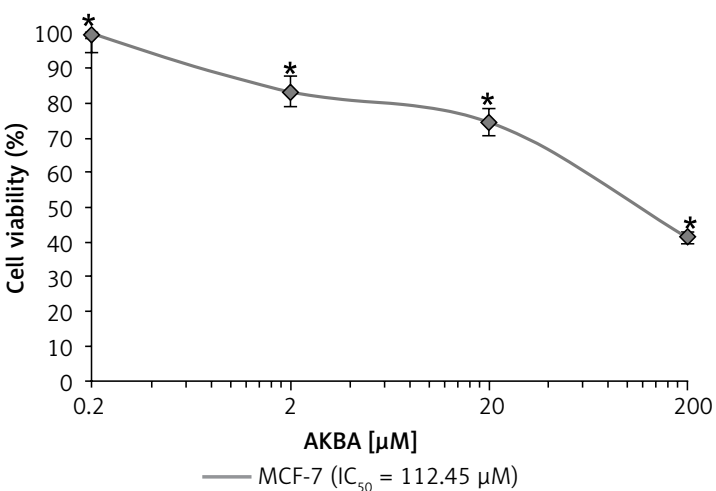

Figure 1. AKBA exhibits an antiproliferative effect on BC cells. A - Effect of AKBA on proliferation of BC cells (MCF-7, BT-474) was determined by MTT assay. B - Effect of AKBA on proliferation of normal breast cells (MCF-10A) determined by MTT assay

The data represent the mean value \pm SE of three independent experiments. ${ }^{*} P<0.05$. 
ising antiproliferative effect on BC cells and is less toxic to normal cells.

\section{AKBA abrogates cell migration and invasion of $B C$ cells}

To examine whether AKBA could also impact tumor cell motility, migration, and invasion in vitro we intended to perform a wound healing assay and Transwell Boyden chamber cell migration assay in vitro to evaluate the anti-migration or anti-invasive potential of AKBA by treating cells with subtoxic concentrations of AKBA in BC cells. Due to the significant induction of cell death at higher concentrations of AKBA, subtoxic concentrations $(10,20$ and $30 \mu \mathrm{M})$ of AKBA for $24 \mathrm{~h}$ were carefully selected to study the anti-motility and anti-invasive effect on BC cells. Our results revealed that a significant reduction in motility of cells was witnessed once BC cells (MCF-7, BT-474) were exposed to 20 and $30 \mu \mathrm{M}$ of AKBA, which is as good as positive control staurosporine ( $25 \mathrm{nM})$ (Figures $2 \mathrm{~A}, \mathrm{~B}$ ), after creating a wound by making a scratch with a $100 \mu$ l sterile tip when compared to a control DMSO that was almost filled with migrated cells.

A crucial step of metastatic cells is the capability of these cells to migrate across the various barriers including the extracellular matrix and disseminate the migrated cells away from the primary tumor site. To study the influence of AKBA on the invasive property of cancer cells, we intended to perform a Transwell Boyden chamber assay to determine the inhibitory capability of AKBA on BC cell migration and invasion through the porous biological membrane inserts in vitro. Our results demonstrated that a significant number of invaded cells lost the ability to penetrate through the Matrigel-coated membrane in a dose-dependent manner, when compared to control DMSO (Figure 2 C). The bar diagram (Figure $2 \mathrm{D}$ ) shows that the number of invaded cells is 42,32 , and 13 at a concentration of 10,20 , and $30 \mu \mathrm{M}$ of AKBA respectively, as compared to 145 invaded cells in control DMSO. Collectively, these results indicate that subtoxic doses of AKBA attenuate the growth kinetics of $B C$ cells.

\section{AKBA induces apoptosis in BC cells}

In the previous section, the antiproliferative effect of AKBA on BC cells was discussed. Next, to determine whether the AKBA-mediated antiproliferative effect induces apoptosis in BC cells, we performed the annexin $V$ FITC detection assay after treating $B C$ cells with AKBA in a concentration-dependent manner. Our results demonstrated that AKBA pushes a significant population of cells towards apoptosis as evidenced by $14.5 \%$ and $25.3 \%$ at 30 and $40 \mu \mathrm{M}$ of AKBA respectively in BC cells as compared to $35.9 \%$ apoptotic population of staurosporine (positive control) and 2.1\% of control DMSO (Figures $3 \mathrm{~A}, \mathrm{~B}$ ). Moreover, to confirm the mechanism associated with AKBA-induced apoptosis, the immunoblotting analysis revealed that the initiation of caspase-3, as well as PARP1 activation, takes place as evidenced by increased caspase- 3 and PARP1 cleavage activity after exposing $B C$ cells to dose-dependent concentrations $(20,30,40 \mu \mathrm{M})$ of AKBA (Figures $3 \mathrm{C}, \mathrm{D}$ ). Furthermore, phase contrast microscopy revealed that a significant number of apoptotic dead and floated cells were seen after $B C$ cells were treated with 30 and $40 \mu \mathrm{M}$ of AKBA concentration for $24 \mathrm{~h}$, as compared to control DMSO cells (Figure $3 \mathrm{E}$ ). Together, our results demonstrate that the antiproliferative effect exerted by AKBA is due to the induction of apoptosis as evidenced by prominent caspase- 3 and PARP1 cleavage.

\section{AKBA inhibits matrix MMP-2 and MMP-9 activity and expression in $\mathrm{BC}$ cells}

Besides cell motility, invasion and migration, a metastatic cell needs proteolytic cleavage of the matrix to disseminate the cells to distant sites. Increased expression, as well as activity of MMPs, has been associated with cancer cell metastasis. As AKBA exerts an anti-migration effect on $B C$ cells, we intended to investigate whether AKBA could display anti-gelatinase activity on BC cells. As shown in Figures 4 A, B, gelatin zymography demonstrated that significant abrogation of gelatinase activity of MMP-9 and MMP-2 in conditional medium samples was seen, after collection of conditional medium from BC cells exposed to AKBA in concentration-dependent fashion for $24 \mathrm{~h}$. Further, we investigated whether AKBA could modulate the MMP-9 and MMP-2 expression. As shown in Figure 3, immunoblotting results revealed that AKBA displays a significant decrease in both MMP-9 and MMP-2 expression in a concentration-dependent manner (Figures 4 C, D). Collectively, these results suggest that AKBA effectively abrogates both the expression as well as the activity of MMP-9 and MMP- 2 in a dose-dependent manner.

\section{AKBA inhibits EGFR mediated PI3K/Akt pathway and showed a strong synergistic effect with $B C$ inhibitors}

Previous reports suggest that the strong correlation of EGFR mutation and post-EGFR signaling pathway activation in BC cells plays a critical role in invasion and metastasis of tumor cells. Therefore, we intended to explore whether AKBA could inhibit EGFR and its post-EGFR signaling in 
A

$\mathrm{h}$

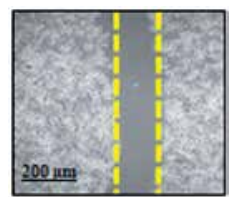

$24 \mathrm{~h}$

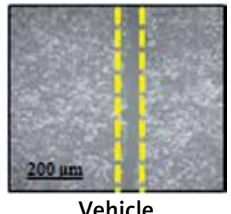

Vehicle

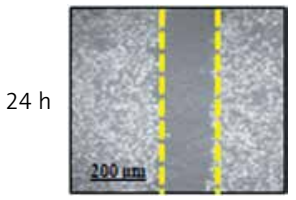

AKBA $10 \mu \mathrm{M}$
MCF-7 cells

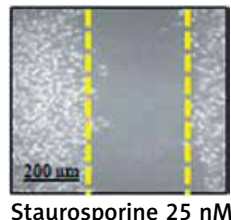

\section{AKBA $20 \mu \mathrm{M}$}

B
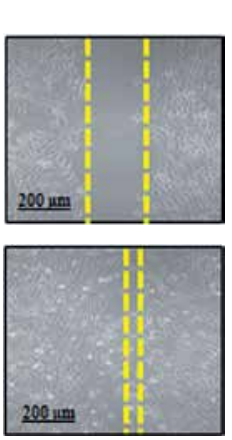

Vehicle

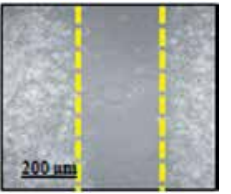

AKBA $30 \mu \mathrm{M}$

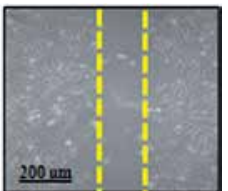

AKBA $10 \mu \mathrm{M}$
BT474 cells
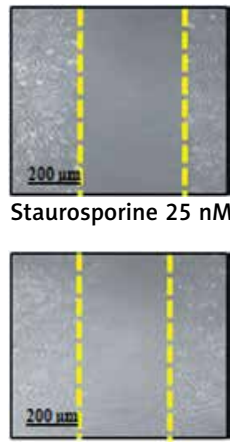

AKBA $20 \mu \mathrm{M}$

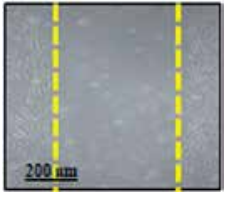

AKBA $30 \mu \mathrm{M}$
C

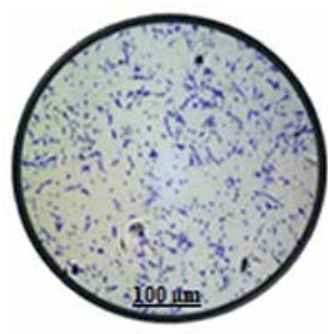

Control

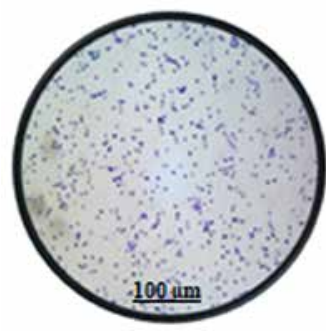

AKBA $20 \mu \mathrm{M}$

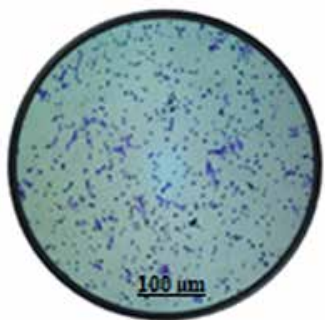

AKBA $10 \mu \mathrm{M}$

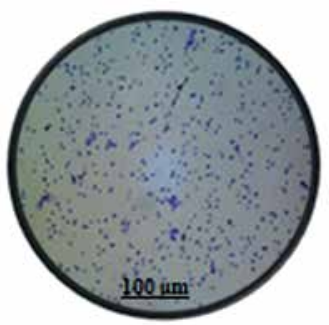

AKBA $30 \mu \mathrm{M}$

D

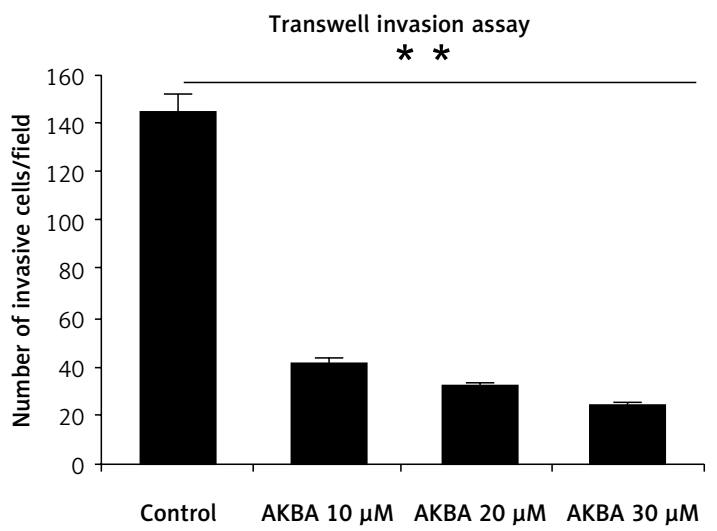

Figure 2. AKBA abrogates cell migration and invasion of BC cells (A) and (B) BC cells (MCF-7, BT-474) were exposed to indicated concentrations of $\operatorname{AKBA}(10,20,30 \mu \mathrm{M})$ along with staurosporine $(25 \mathrm{nM})$ as a positive control and DMSO as a control) for $24 \mathrm{~h}$ to evaluate the anti-motility effect of AKBA on BC cells. Scale bar: $200 \mu \mathrm{m} ; 10 \times$. C - Cell invasion was determined by the Transwell Boyden chamber assay. Briefly, $2 \times 10^{5}$ cells/well were seeded in the top chamber in the presence of AKBA along with control DMSO. Cells were allowed to migrate for $24 \mathrm{~h}$; cells able to cross the porous membrane from the bottom half of the insert membrane were stained with $0.1 \%$ crystal violet and counted under phase contrast microscope. Five fields were counted in triplicate from each insert of three independent experiments. Scale bar: $100 \mu \mathrm{m} ; 20 \times$. D - Bar diagram showing quantification of invasive cells after exposure with varying concentrations of AKBA

The data represent the mean value \pm SE of three independent experiments. ${ }^{* *} P<0.01$

BC cells. As shown in Figures $5 \mathrm{~A}$ and $\mathrm{B}$, the immunoblotting results of $B C$ cell lysates treated with dose-dependent concentration $(20,30,40 \mu \mathrm{M})$ of AKBA inhibits protein expression of EGFR as well as phosphorylation status of $p$-EGFR-Tyr1173. The post-signaling PI3K/Akt pathway modulated by EGFR plays a major role in transmitting extracellular signal transduction to cellular responses of
$B C$ cells to regulate tumor cell invasion. To determine whether AKBA could also affect the PI3K/AKt signaling, our immunoblotting results revealed a significant reduction in phosphorylation of PI3K$\mathrm{P} 110 \alpha$ and $\mathrm{p}-\mathrm{AKT}$-Ser473. However, no change was observed in the expression pattern of total Akt when BC cells were exposed to dose-dependent concentrations $(20,30,40 \mu \mathrm{M})$ of AKBA for 

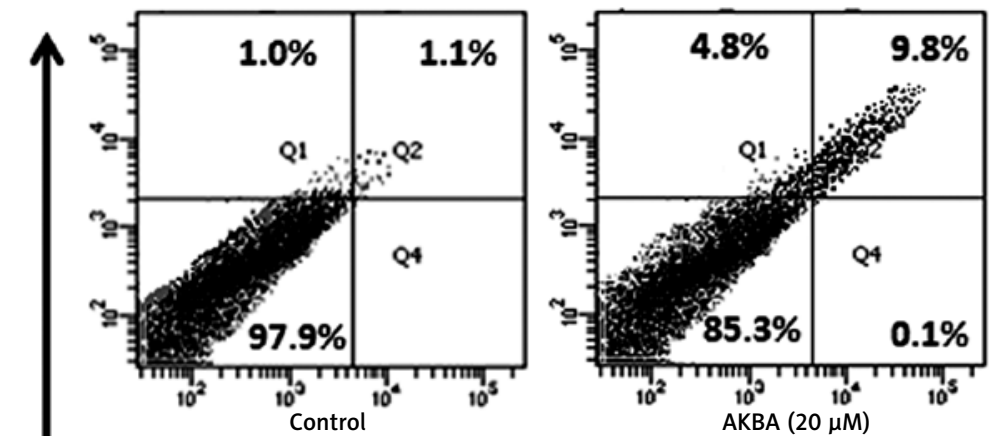

PI
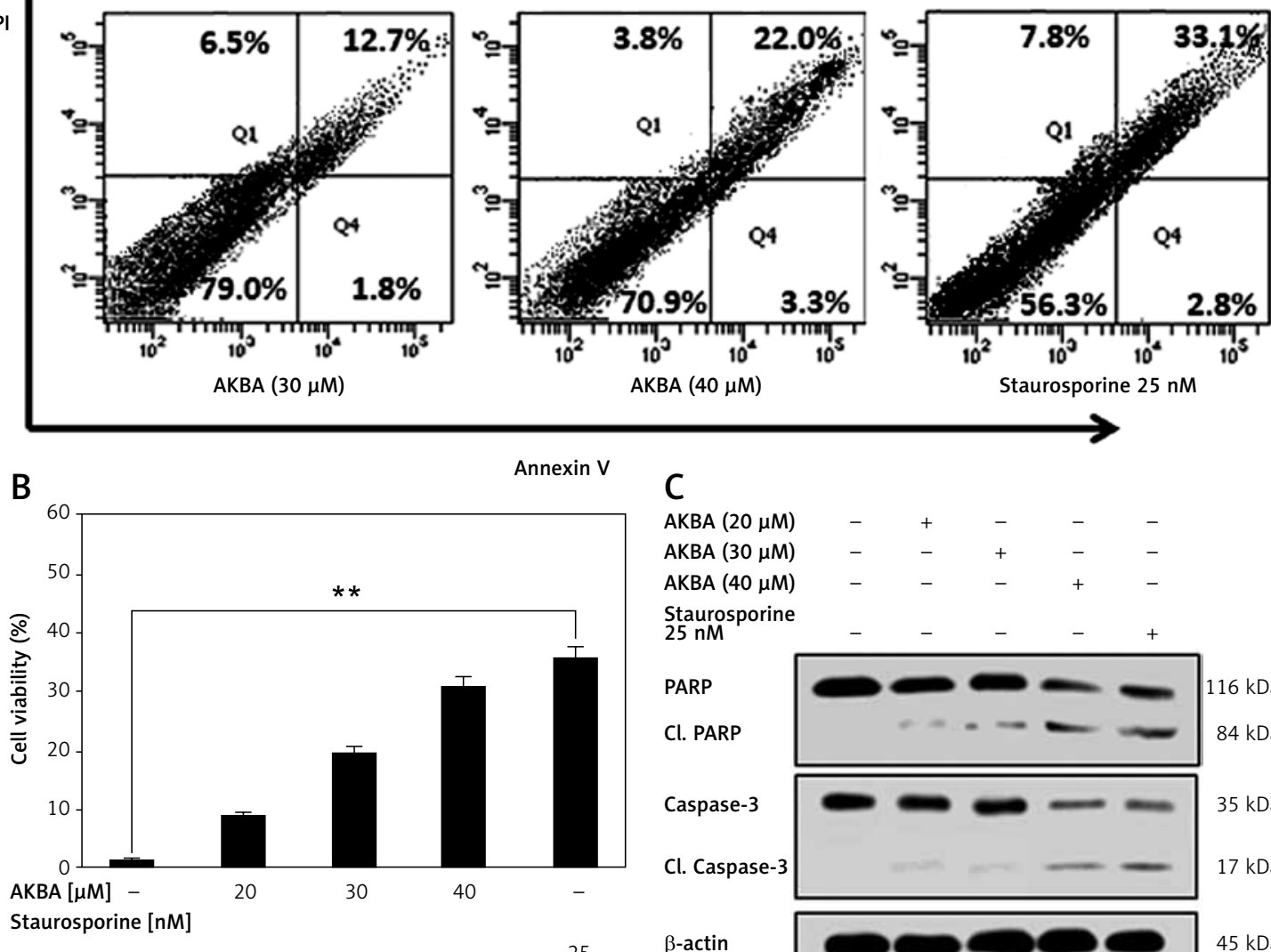

C

AKBA $(20 \mu \mathrm{M})$ AKBA $(30 \mu \mathrm{M})$ AKBA $(40 \mu \mathrm{M})$ Staurosporine

PARP

Cl. PARP

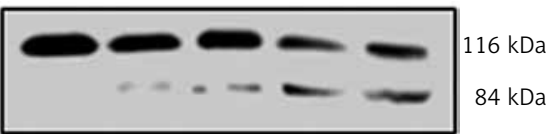

Caspase-3

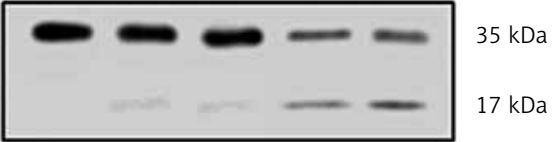

Cl. Caspase-3

$\beta$-actin

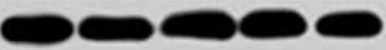
$45 \mathrm{kDa}$

D

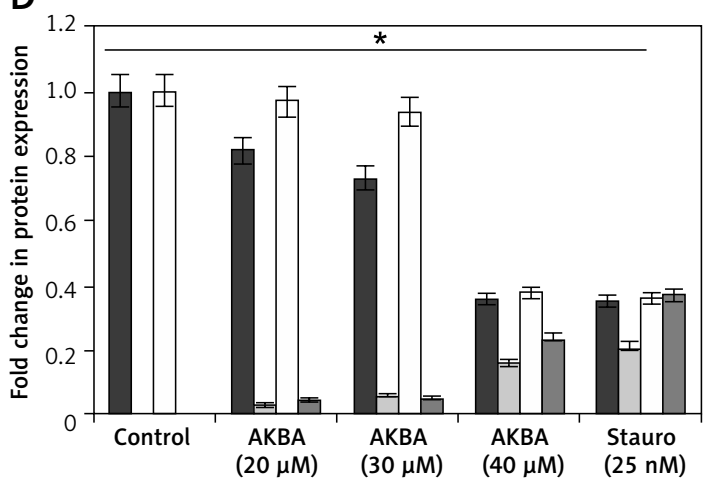

E
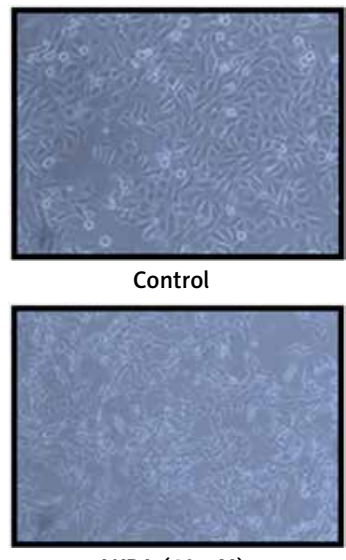

AKBA $(40 \mu M)$

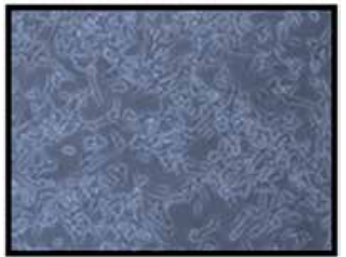

AKBA $(30 \mu \mathrm{M})$

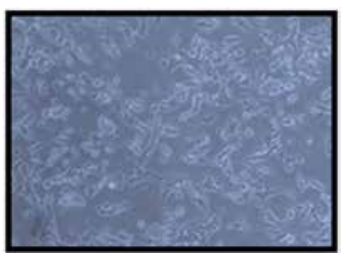

Staurosporine $25 \mathrm{nM}$

Figure 3. AKBA induces apoptosis in BC cells. A-BC cells (MCF-7) were treated with varying $(20,30,40 \mu \mathrm{M})$ concentrations of AKBA along with staurosporine $(25 \mathrm{nM})$ as positive control and DMSO as a control for $24 \mathrm{~h}$ and then exposed to staining solution of Annexin V FITC and propidium iodide and analyzed by FACS. B - Bar diagram showing quantification of Annexin V FITC positive cells analyzed by FACS. C - Immunoblotting analysis showing prominent PARP1 and caspase- 3 cleavage in lanes 4 and 5 where cells were exposed to AKBA and staurosporine treatment and internal control $\beta$-actin. $\mathbf{D}$ - Densitometry analysis represented by histogram shows the fold change in protein expression after normalization with $\beta$-actin. $\mathbf{E}$ - Representative micrograph images by phase-contrast microscopy of BC cells exposed to indicate doses of AKBA and positive control staurosporine. Scale bar: $100 \mu \mathrm{m} ; 20 x$

The data denote the mean value \pm SE of three independent unbiased experiments. ${ }^{*} P<0.05,{ }^{* *} p<0.01$. 
A

AKBA $(20 \mu M)$
AKBA $(30 \mu M)$

AKBA $(40 \mu \mathrm{M})$

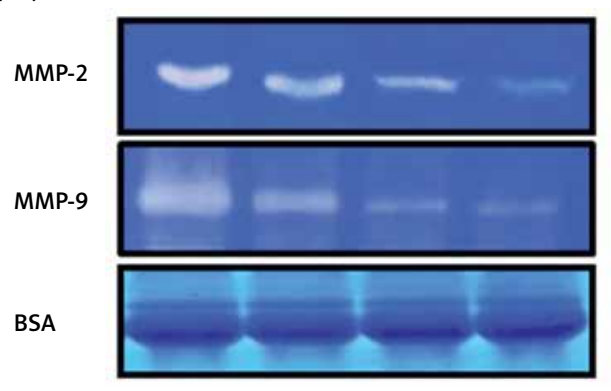

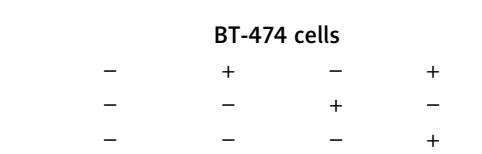

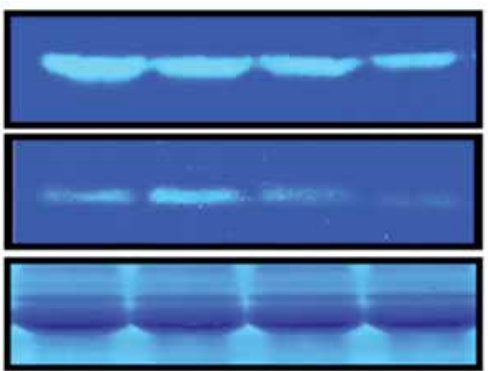

$72 \mathrm{kDa}$

$92 \mathrm{kDa}$

$68 \mathrm{kDa}$

B

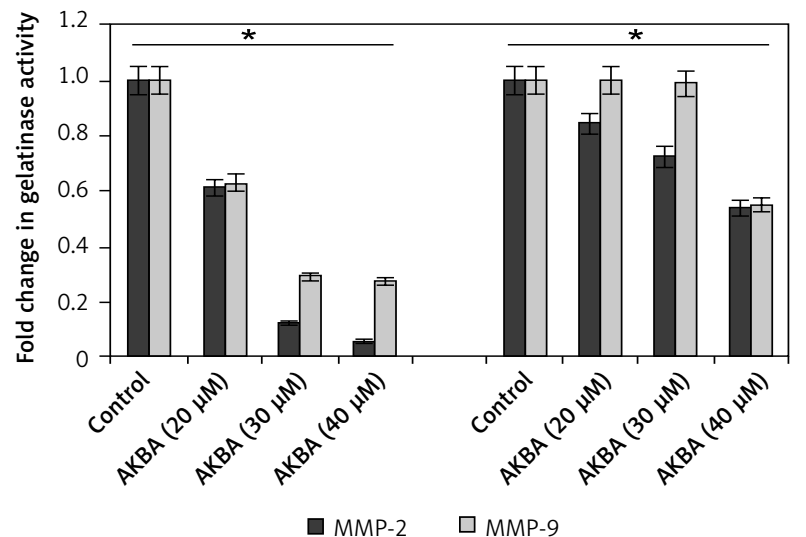

C

AKBA $(20 \mu \mathrm{M})$

AKBA $(30 \mu \mathrm{M})$

AKBA $(40 \mu \mathrm{M})$

MMP-2
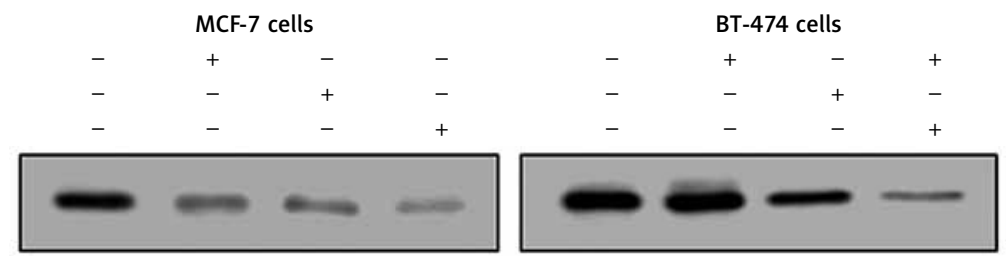

$72 \mathrm{kDa}$
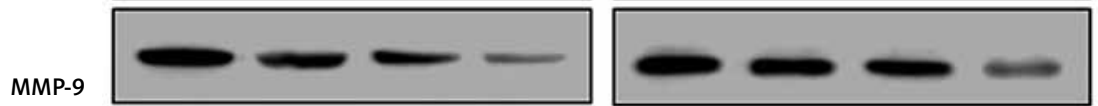

$92 \mathrm{kDa}$

$\beta$-Actin
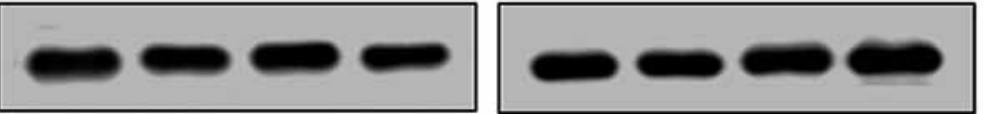

$45 \mathrm{kDa}$

D

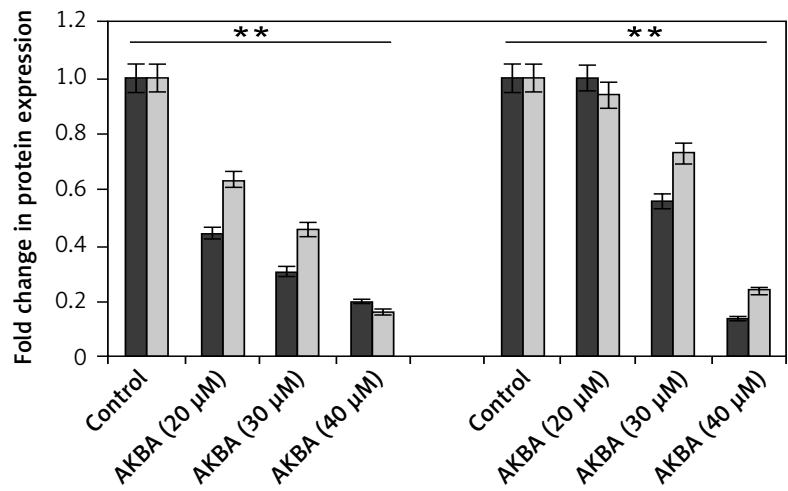

$\square$ MMP-2 $\square$ MMP-9

Figure 4. AKBA inhibits matrix MMP-2 and MMP-9 activity and expression in BC cells. A - BC cells (MCF-7, BT474) were exposed to varying concentrations of AKBA for $24 \mathrm{~h}$ along with control DMSO; conditioned medium was analyzed for MMP-2 and MMP-9 gelatinase activity. B - Representative histogram, shows the fold change in gelatinase activity. C - Immunoblotting analysis of BC cells (MCF-7, BT-474) exposed to different concentrations of AKBA along with control DMSO shows the steady decrease in expression of MMP-2 and MMP-9 proteins along with $\beta$-actin as an internal control. D - Densitometry analysis represented by histogram shows the fold change in protein expression after normalization with $\beta$-actin

The data denote the mean value $\pm S E$ of three independent unbiased experiments. ${ }^{*} P<0.05,{ }^{* *} p<0.01$. 
A

AKBA $(20 \mu \mathrm{M})$

AKBA $(30 \mu \mathrm{M})$

AKBA $(40 \mu \mathrm{M})$

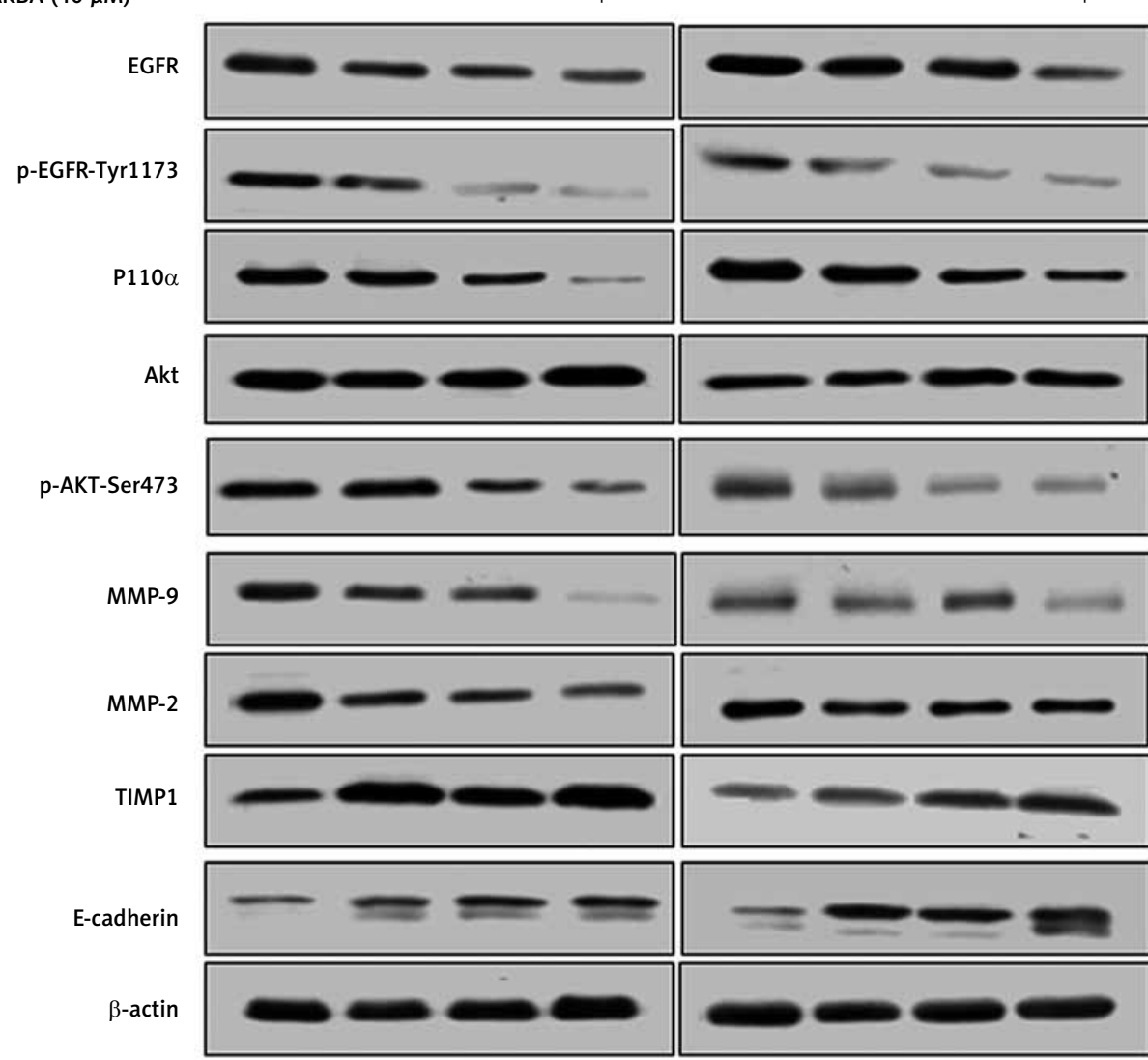

$175 \mathrm{kDa}$

$185 \mathrm{kDa}$

$110 \mathrm{kDa}$

$60 \mathrm{kDa}$

$60 \mathrm{kDa}$

92 kDa

$72 \mathrm{kDa}$

$26 \mathrm{kDa}$

$135 \mathrm{kDa}$

$45 \mathrm{kDa}$

B

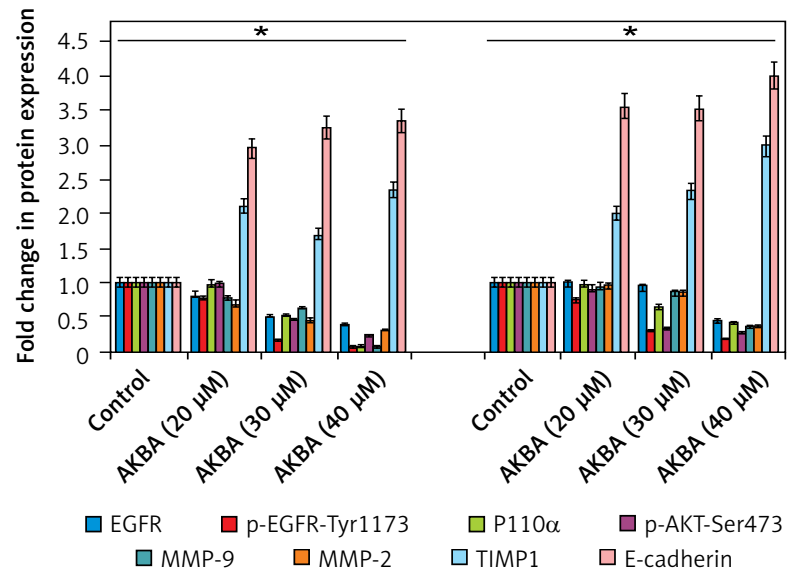

Figure 5. AKBA inhibits EGFR-mediated PI3K/Akt pathway and showed a significant inhibitory effect and strong synergistic effect with gefitinib and erlotinib in BC cells. A - Immunoblotting analysis of BC cells (MCF-7, BT-474) exposed to varying concentrations of AKBA $(20,30,40 \mu \mathrm{M})$ shows the expression pattern of EGFR and post-EGFR signaling associated proteins (p-EGFR-Tyr1173, P110 $\alpha$, Akt, p-Akt-Ser473, MMP-9, MMP-2, TIMP1, E-cadherin) along with $\beta$-actin as an internal control. $\mathbf{B}$ - Densitometry analysis represented by histogram shows the fold change in protein expression after normalization with $\beta$-actin

The data denote the mean value $\pm S E$ of three independent unbiased experiments. ${ }^{*} P<0.05$. 

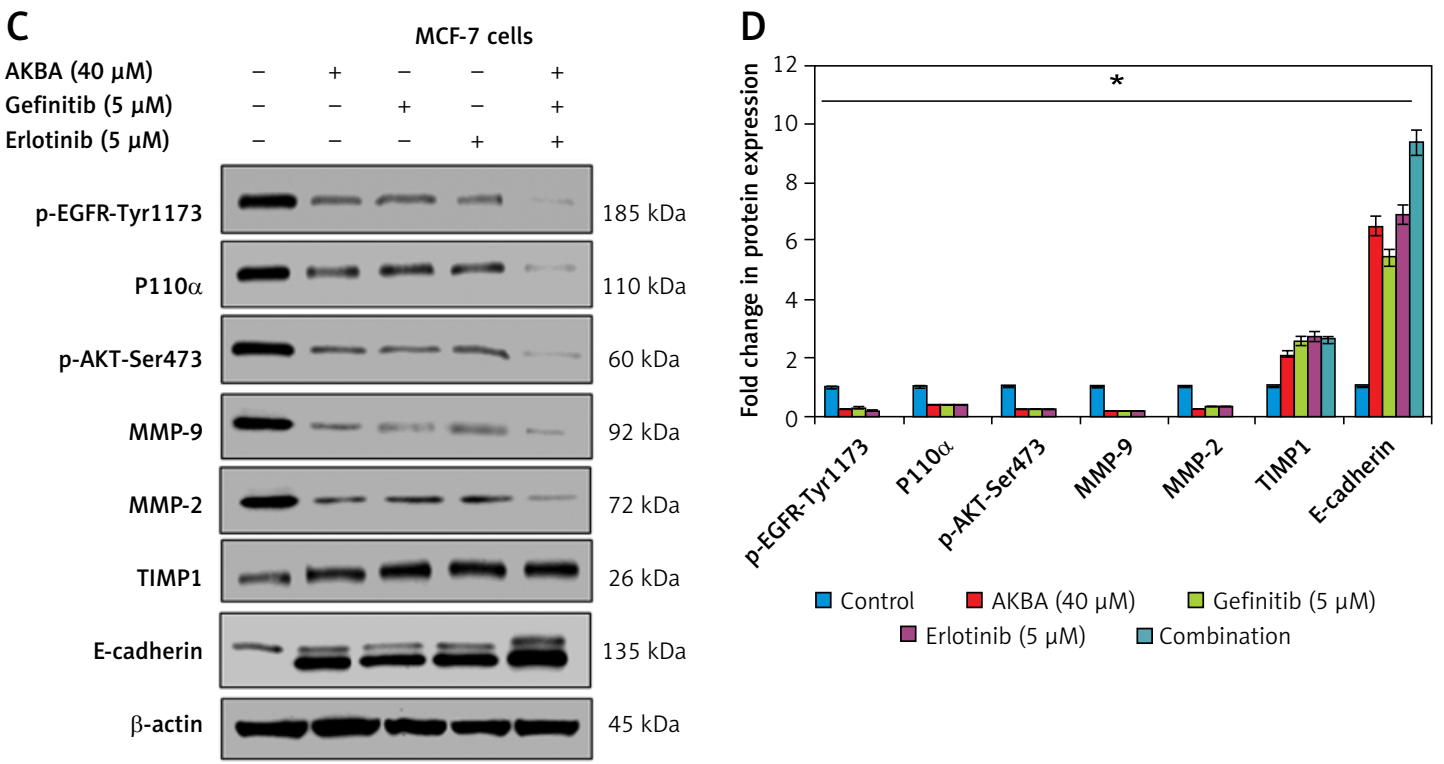

Figure 5. Cont. C - Immunoblotting analysis of BC cells (MCF-7) exposed to concentrations of AKBA (40 $\mu M$ ), gefitinib $(5 \mu \mathrm{M})$, erlotinib $(5 \mu \mathrm{M})$ along with untreated control and combination (AKBA $40 \mu \mathrm{M}+$ gefitinib $5 \mu \mathrm{M}$ + erlotinib $5 \mu \mathrm{M}$ ) shows the expression pattern of EGFR-mediated PI3K/Akt signaling associated proteins along with $\beta$-actin as an internal control. D - Densitometry analysis represented by histogram shows the fold change in protein expression after normalization with $\beta$-actin

The data denote the mean value \pm SE of three independent unbiased experiments. ${ }^{*} P<0.05$

24 h. Could downregulation of PI3K/Akt signaling proteins by AKBA also attenuate the expression of MMPs which play a critical role in tumor cell invasion? Our results revealed that upon treatment with dose-dependent concentrations $(20,30,40 \mu \mathrm{M})$ of AKBA for $24 \mathrm{~h}$, we observed a drastic reduction in the MMP-2 and MMP-9 with concomitant induction in the expression of E-cadherin and TIMP1. Collectively these results demonstrate that AKBA attenuates EGFR activation, which in turn abrogates post-EGFR PI3K/Akt and downstream associated proteins MMP-2 and MMP-9 that regulate tumor cell invasion in BC cells.

Next, we sought to evaluate the comparative inhibitory and synergistic effect of AKBA on EGFR-mediated PI3K/Akt proteins with known inhibitors (gefitinib and erlotinib) in MCF-7 cells. We designed an experiment to expose cells with the highest concentration of AKBA $(40 \mu \mathrm{M})$, gefitinib $(5 \mu \mathrm{M})$, erlotinib $(5 \mu \mathrm{M})$, and combination (AKBA $40 \mu \mathrm{M}+$ gefitinib $5 \mu \mathrm{M}$, erlotinib $5 \mu \mathrm{M})$ along with untreated cells as a control for $24 \mathrm{~h}$. Our immunoblotting results demonstrate that AKBA $(40 \mu \mathrm{M})$ significantly inhibits protein expression of EGFR-mediated PI3K/Akt signaling associated proteins ( $p$-EGFR-Tyr1173, PI3K-P110 $\alpha$, p-AKTSer473, MMP-9 and MMP-2) and increases the expression of TIMP1 and E-cadherin; however, when compared to known inhibitors, the effect is as good as that of gefitinib $(5 \mu \mathrm{M})$ and erlotinib $(5 \mu \mathrm{M})$ at their respective concentrations (Figures 5 C, D). Interestingly, the combination (AKBA
$40 \mu \mathrm{M}+$ gefitinib $5 \mu \mathrm{M}$, erlotinib $5 \mu \mathrm{M})$ shows a strong synergistic effect on EGFR-mediated $\mathrm{PI3K} /$ Akt signaling proteins by drastically downregulating the expression of p-EGFR-Tyr1173, PI3K-P110 $\alpha$, p-AKT-Ser473, MMP-9, and MMP-2 and concomitantly upregulating the expression of TIMP1 and E-cadherin proteins significantly when compared to cells exposed to AKBA $40 \mu \mathrm{M}$, gefitinib $5 \mu \mathrm{M}$, and erlotinib $5 \mu \mathrm{M}$ alone. Collectively, these results demonstrated that AKBA effectively targets and inhibits the EGFR-mediated PI3K/AKt signaling proteins and the effect is significant as compared to known inhibitors (gefitinib and erlotinib). However, the combination of AKBA, gefitinib and erlotinib has a strong synergistic effect and almost abolishes the expression of EGFR and downstream associated PI3K/Akt signaling associated proteins.

EGF reverses the AKBA inhibitory effect on EGFR and post-signaling PI3K/Akt pathway

To investigate whether the EGF could restore the activation of EGFR-mediated PI3K/Akt activation and neutralize any inhibitory effect of AKBA on tumor cell invasion, a two-set experiment was designed to confirm whether EGF could restore the stimulation of the EGFR-mediated PI3K/AKt signaling pathway. In the first set $B C$ cells were pre-treated with $\operatorname{EGF}(30,40,50 \mathrm{ng} / \mathrm{ml})$ and in the second set without EGF, followed by dose-dependent $(20,30,40 \mu \mathrm{M})$ treatment with AKBA for $24 \mathrm{~h}$ in both the sets. As shown in Figures $6 \mathrm{~A}$ and $\mathrm{B}$, 
A

AKBA $(20 \mu \mathrm{M})$

AKBA $(30 \mu \mathrm{M})$

AKBA $(40 \mu \mathrm{M})$

$\mathrm{EGF}[\mathrm{ng} / \mathrm{ml}]$

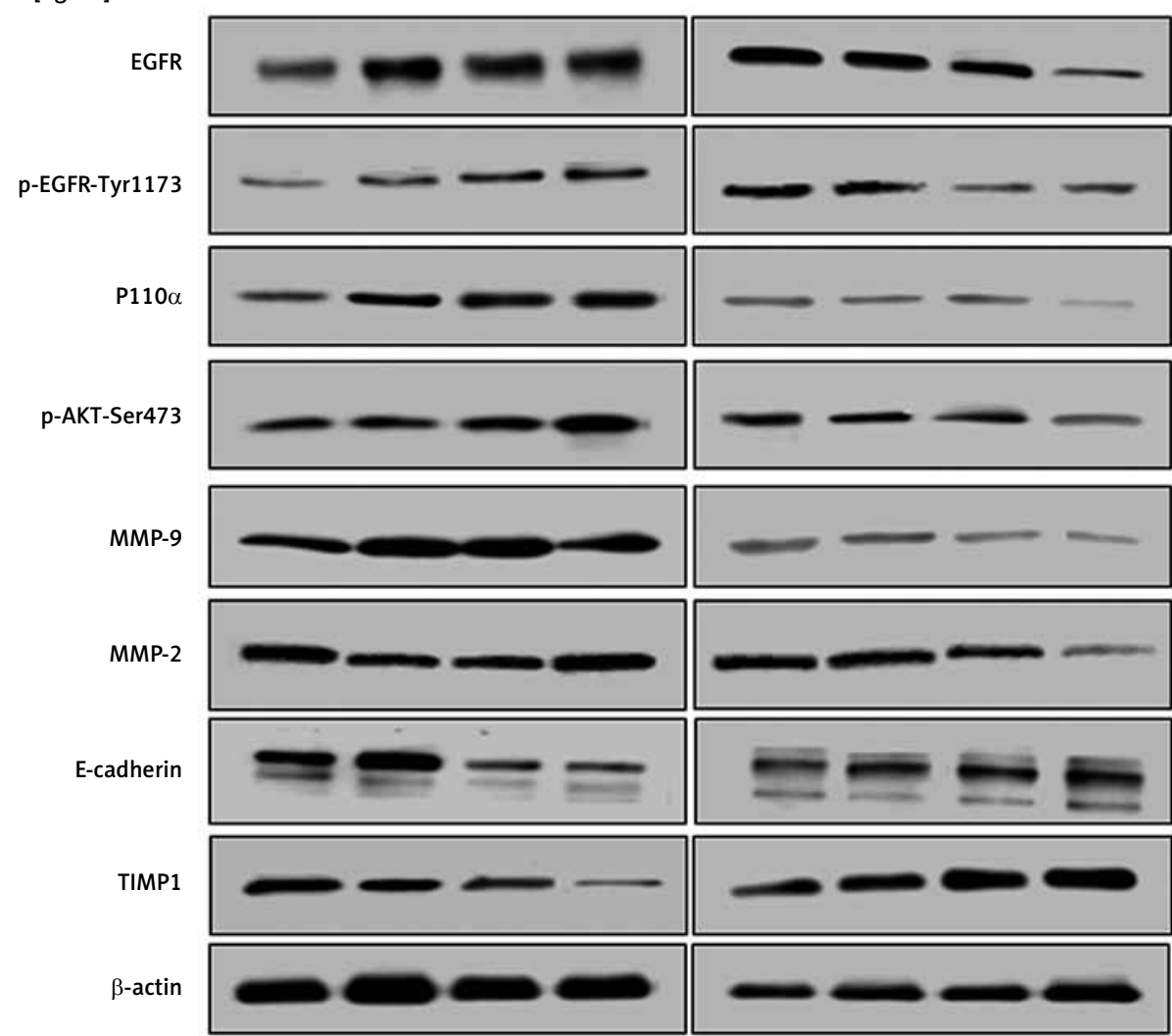

$175 \mathrm{kDa}$

$185 \mathrm{kDa}$

$110 \mathrm{kDa}$

$60 \mathrm{kDa}$

$92 \mathrm{kDa}$

$72 \mathrm{kDa}$

$135 \mathrm{kDa}$

26 kDa

$45 \mathrm{kDa}$

B

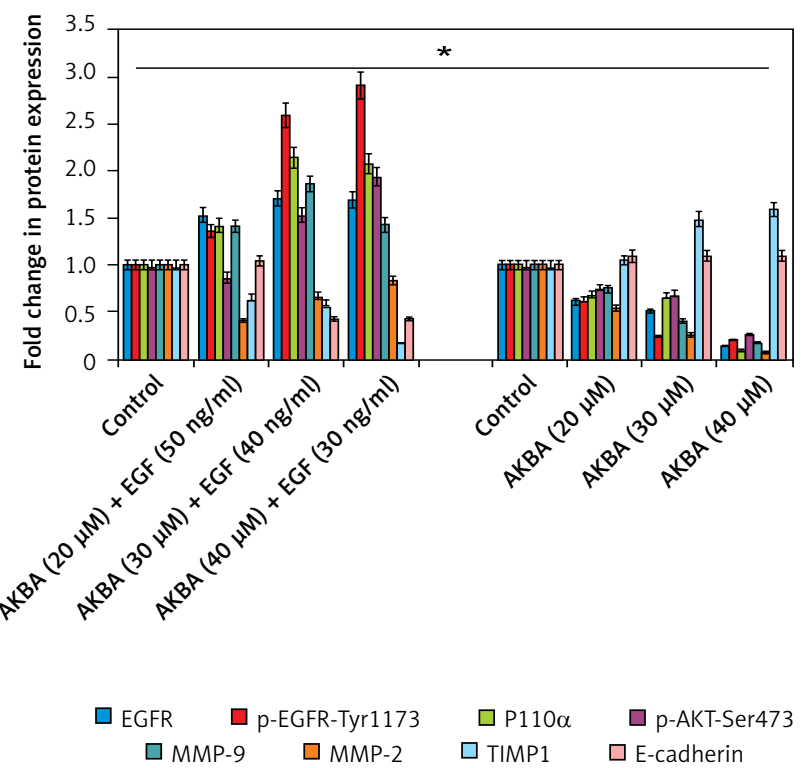

Figure 6. EGF restores EGFR and post-signaling PI3K/Akt pathway activation inhibited by AKBA in BC cells. A - Immunoblotting analysis of $B C$ cells (MCF-7) exposed to different concentrations AKBA, which were initially pre-treated with $\operatorname{EGF}(30,40,50 \mathrm{ng} / \mathrm{ml})$ in one set and another set is exposed to only AKBA, shows the expression pattern of EGFR and post-EGFR signaling proteins (p-EGFR-Tyr1173, P110 $\alpha$, Akt, p-Akt-Ser473, MMP-9, MMP-2, TIMP1, E-cadherin) along with $\beta$-actin as an internal control. B - Densitometry analysis represented by histogram shows the fold change in protein expression after normalization with $\beta$-actin

The data represent the mean value $\pm S E$ of three independent experiments. ${ }^{* *} P<0.01$. 

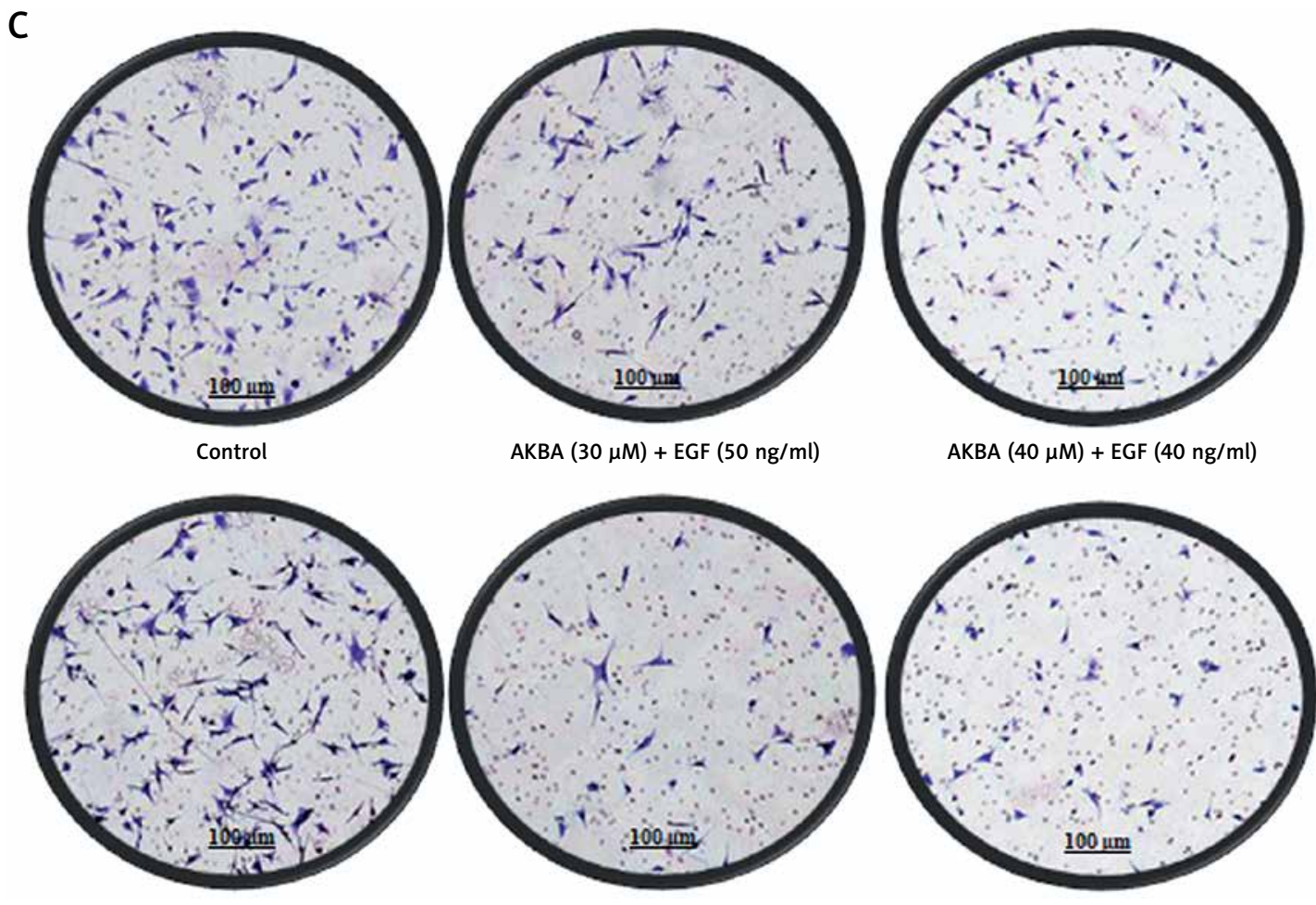

AKBA $(30 \mu \mathrm{M})+E G F(50 \mathrm{ng} / \mathrm{ml})$

AKBA $(40 \mu M)+E G F(40 \mathrm{ng} / \mathrm{ml})$

Control

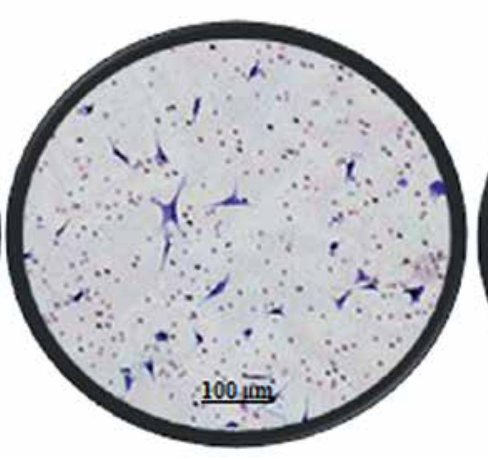

AKBA $(30 \mu M)$

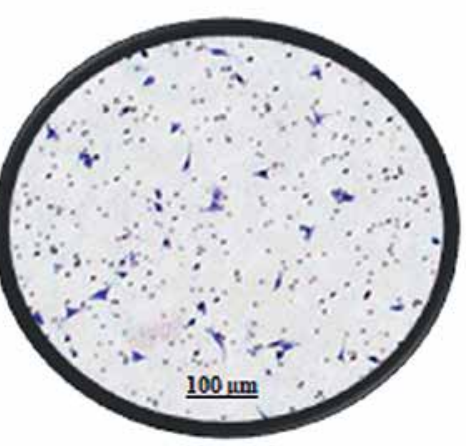

AKBA $(40 \mu M)$

D

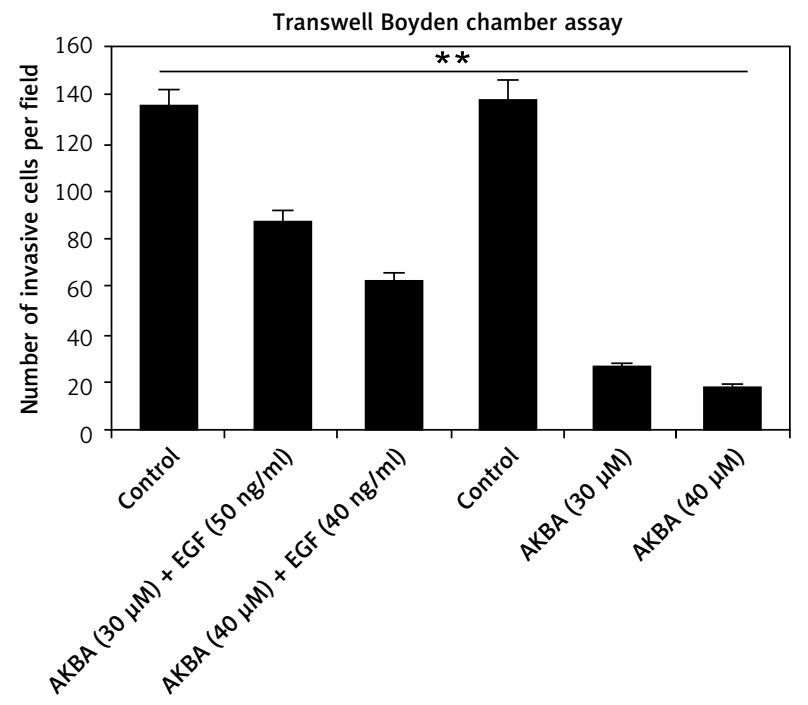

Figure 6. Cont. C - BC cell invasion was determined by the Transwell Boyden chamber assay. Briefly, $2 \times 10^{5}$ cells/ well was seeded in the top chamber in the presence of varying concentrations of AKBA along with control DMSO, which were pre-treated with $\operatorname{EGF}(40,50 \mathrm{ng} / \mathrm{ml})$ in one set and in another set only AKBA. Cells were allowed to migrate for $24 \mathrm{~h}$, at which point migratory cells on the bottom half of the insert membrane were stained with $0.1 \%$ crystal violet and counted under a phase contrast microscope. Five fields were counted in triplicate from each insert of three independent experiments. Scale bar: $100 \mu \mathrm{m}$; 20x. D - Bar diagram showing quantification of invasive cells after exposure with varying concentrations of AKBA and pre-treated with EGF in one set and another set treated with AKBA only

The data represent the mean value $\pm S E$ of three independent experiments. ${ }^{*} P<0.01$.

interestingly, the immunoblotting results demonstrated that the BC cells pre-treated with EGF followed by AKBA treatment have upregulated EGFR, MMP-9 and MMP-2, expression as well as a significant increase in phosphorylation of EGFR
(p-EGFR-Tyr1173), and p-Akt with a concomitant decrease in E-cadherin and TIMP1 protein expression. However, BC cells exposed to AKBA only had a significant reduction in EGFR, MMP-2, and MMP-9 protein expression as well as phosphor- 
ylation of EGFR ( $p$-EGFR-Tyr1173) and p-Akt with simultaneous induction of E-cadherin and TIMP1 expression. Additionally, Transwell Boyden chamber invasion assay results reveal that the BC cells pre-treated with EGF $(40,50 \mathrm{ng} / \mathrm{ml})$ followed by dose-dependent $(30,40 \mu \mathrm{M})$ treatment of AKBA for $24 \mathrm{~h}$ have a number of invasive cells similar to as that of control DMSO (Figures $6 \mathrm{C}, \mathrm{D}$ ). However, cells treated with AKBA $(20,30,40 \mu \mathrm{M})$ only have significantly fewer invasive cells than control DMSO cells. Collectively, these results indicate that AKBA inhibits EGFR-mediated PI3K/Akt signaling and its downstream targets which regulate cell invasion and metastasis.

\section{Discussion}

Boswellic acids are the main components of gum resin obtained from the plant Boswellia serrata. Since ancient times the Indian traditional Ayurveda system of medicine has been using boswellic acid components to treat various inflammatory ailments which include ulcerative colitis, bronchial asthma, chronic colitis, Crohn's disease and osteoarthritis [20, 26]. Among the boswellic acids, AKBA is one of the active non-redox components and has been reported to inhibit 5-lipooxygenase by acting as a non-competitive inhibitor [28, 29]. Recently AKBA has gained tremendous attention as a promising chemopreventive natural compound. Numerous studies have demonstrated the anti-cancer effect of AKBA against a wide variety of human cancer cells [30]. Moreover, AKBA exerts anti-tumor activity by modulating a plethora of molecules that play a crucial role in the development of tumorigenesis [31]. A growing body of evidence has revealed that AKBA exerts an antiproliferative effect in colorectal cancer cells by influencing miRNAs (let-7 and miR-200 family) [32]. However, AKBA exhibits an antiproliferative effect by triggering G2/M phase cell cycle arrest in glioblastoma cells [33]. Additionally, in pancreatic cancer cells, AKBA suppresses the invasiveness as well as motility of tumor cells by impairing cysteine $X$ chemokine receptor 4 (CXCR4) expression [22]. Consistent with these results, we note that AKBA exerts an antiproliferative effect by inducing apoptosis in luminal subtype A (MCF-7) and subtype B (BT-474) $B C$ cells. Importantly, the current study found that AKBA inhibits cell migration and invasion by attenuating EGFR-mediated post-PI3K/Akt signaling and downregulates its downstream targets MMP-9 and MMP-2 activity and expression with the simultaneous increase in E-cadherin and TIMP-1 expression in $B C$ cells. These findings demonstrate that AKBA could be a potential chemopreventive agent in the therapeutics of BC patients.

Naturally occurring chemopreventive agents are an important source of drugs against many dis- eases including cancer. Almost half of the FDA-approved pharmaceutical drugs are derived either from plants directly or from plant derivatives [34]. Still, there is a scope for more drugs with high efficacy towards cancer cells and minimal toxicity towards normal cells. AKBA is a pentacyclic triterpenoid naturally occurring chemopreventive agent that exhibits numerous pharmacological properties such as neuroprotective, anti-oxidative, anti-inflammatory and antitumor activity by suppressing cell migration and invasion and triggering cell cycle arrest as well as induction of apoptosis in tumor cells $[33,35-37]$. Therefore, it is necessary to evaluate the antiproliferative potential of AKBA and elucidate the underlying inhibitory mechanism against $B C$ cells. Our results revealed that AKBA displays a strong antiproliferative effect by reducing cell viability of $B C$ cells significantly, but in transformed normal breast cells (MCF-10A), AKBA exerts a cytotoxic effect significantly at high concentration $\left(\mathrm{IC}_{50}=112.45 \mu \mathrm{M}\right)$, indicating that AKBA specifically exhibits an antiproliferative effect on cancer cells and shows minimal toxicity toward normal cells.

Park et al. demonstrated that AKBA exhibited an antiproliferative effect in pancreatic cancer cells by downregulating the expression of CXCR4 at the transcriptional level. Interestingly, the reduction of CXCR4 expression leads to the attenuation of cell invasion and migration properties of pancreatic malignant cells [22]. Similarly, Parr et al. showed that Boswellia frereana extract significantly inhibits hepatocyte growth factor (HGF)mediated cell migration and invasion in BC cells by modulating the c-Met signaling pathway [38]. Consistent with previous studies, we observed that AKBA causes significant reduction in motility of $B C$ cells. To discourse any rational discrimination of AKBA in modulating cell migration with apoptosis, we cautiously select subtoxic concentrations and found that $20 \mu \mathrm{M}$ AKBA did not induce cell killing significantly but altered cell migration significantly even at subtoxic doses when compared to untreated cells which were filled with migrated cells. A crucial step of metastatic cells is the capability of these cells to migrate across various barriers including extracellular matrix and disseminate the migrated cells away from the primary tumor site [39]. Interestingly, the Transwell Boyden chamber invasion assay also supports the notion that subtoxic concentrations of AKBA significantly inhibit the number of invading cells penetrating through a porous biological membrane.

The common mechanism of inducing cell death by natural chemopreventive agents is programmed cell death type I, called apoptosis. The activation of death receptor-mediated apoptosis called the extrinsic apoptosis pathway or the intrinsic apoptosis pathway, which is the mitochon- 
dria-dependent pathway, operates when there is depolarization of mitochondrial membrane potential and liberation of cytochrome C [40]. Previous reports on colorectal cancer and hepatocellular carcinoma revealed that AKBA induces caspase-3 and PARP1 mediated apoptosis [41]. Consistent with the previous reports, we demonstrated that AKBA also activates caspase-3- and PARP1-mediated apoptosis in BC cells.

Accumulating evidence demonstrates that aberrant EGFR-mediated activation of the post$\mathrm{PI} 3 \mathrm{~K} / \mathrm{Akt}$ signaling pathway and its downstream targets is associated with tumor cell proliferation, invasion, and motility in a wide variety of solid malignancies [42]. Moreover, recent reports suggest the strong correlation between hyperactivation of EGFR with cancer metastasis and drug resistance against neoplastic agents [43]. Upon interaction with its respective receptor, EGF stimulates dimerization of the receptor followed by autophosphorylation, which results in the activation of post-PI3K/Akt signaling and associated downstream targets. In our study, we observed that AKBA downregulates both expressions as well as phosphorylation of EGFR and the postEGFR downstream PI3K/Akt signaling pathway in both the BC cell lines. However, we also demonstrated that AKBA significantly downregulates the protein expression of MMP-9 and MMP-2, which play a very vital role in malignant cell invasion and migration. Moreover, AKBA treatment simultaneously augments the protein expression of E-cadherin and TIMP1 in BC cells. Further immunoblotting analysis of $B C$ cells exposed to the highest concentration of AKBA $(40 \mu \mathrm{M})$, along with known inhibitors of EGFR (gefitinib and erlotinib), revealed a significant inhibitory effect on EGFR-mediated downstream PI3K/Akt signaling associated proteins. Interestingly, AKBA showed a strong synergistic effect with gefitinib and erlotinib and almost abolished the expression of EGFR-mediated PI3K/Akt signaling proteins and simultaneously upregulated the expression of TIMP1 and E-cadherin in BC cells. Additionally, we observed that pre-treatment with EGF could restore the ability of BC cell to migrate as well as invade even when exposed to AKBA. Taken together, these results demonstrate that AKBA blocks cell migration and invasion of $B C$ cells which are operated by the EGFR-mediated post-PI3K/Akt signaling pathway.

In conclusion, our results for the first time demonstrate that AKBA exerts an antiproliferative effect by inducing apoptosis and abrogates the metastatic ability of luminal subtype $A$ and subtype $B$ BC cells by downregulating the EGFR-mediated post-PI3K/Akt signaling pathway and associated downstream targets MMP-2 and MMP-9 with simultaneous induction of E-cadherin and TIMP1 expression. Additionally, AKBA showed a significant inhibitory and strong synergistic effect on EGFR-mediated PI3K/Akt signaling associated proteins when compared with the known inhibitors gefitinib and erlotinib. Finally, we demonstrate that AKBA is a promising anticancer therapeutic candidate against $B C$ and could be used in future therapeutics for the prevention and therapy of BC.

\section{Conflict of interest}

The authors declare no conflict of interest.

\section{References}

1. Bray F, Ferlay J, Soerjomataram I, Siegel RL, Torre LA, Jemal A. Global cancer statistics 2018: GLOBOCAN estimates of incidence and mortality worldwide for 36 cancers in 185 countries. CA Cancer J Clin 2018; 68: 394-424.

2. Ruiz R, Herrero C, Strasser-Weippl K, et al. Epidemiology and pathophysiology of pregnancy-associated breast cancer: a review. Breast 2017; 35: 136-41.

3. Koczkodaj P, Sulkowska U, Gotlib J, Mańczuk M. Breast cancer mortality trends in Europe among women in perimenopausal and postmenopausal age (45+). Arch Med Sci 2020; 16: 146-56.

4. Chuthapisith S, Eremin J, El-Sheemey M, Eremin O. Breast cancer chemoresistance: emerging importance of cancer stem cells. Surg Oncol 2010; 19: 27-32.

5. Ying C, Wang S, Lu Y, et al. Glucose fluctuation increased mesangial cell apoptosis related to AKT signal pathway. Arch Med Sci 2019; 15: 730-7.

6. Bianchini G, Balko JM, Mayer IA, Sanders ME, Gianni L. Triple-negative breast cancer: challenges and opportunities of a heterogeneous disease. Nature Rev Clin Oncol 2016; 13: 674-90.

7. Momtazi-Borojeni AA, Nik ME, Jaafari MR, Banach $M$, Sahebkar A. Effects of immunization against PCSK9 in an experimental model of breast cancer. Arch Med Sci 2019; 15: 570-9.

8. Tang P, Skinner KA, Hicks DG. Molecular classification of breast carcinomas by immunohistochemical analysis: are we ready? Diagn Mol Pathol 2009; 18: 125-32.

9. Spanheimer PM, Cyr AR, Gillum MP, Woodfield GW, Askeland RW, Weigel RJ. Distinct pathways regulated by RET and estrogen receptor in luminal breast cancer demonstrate the biological basis for combination therapy. Ann Surg 2014; 259: 793-9.

10. Subik K, Lee JF, Baxter L, et al. The expression patterns of ER, PR, HER2, CK5/6, EGFR, Ki-67 and AR by immunohistochemical analysis in breast cancer cell lines. Breast Cancer 2010; 4: 35-41.

11. Soysal SD, Muenst S, Barbie T, et al. EpCAM expression varies significantly and is differentially associated with prognosis in the luminal B HER2+, basal-like, and HER2 intrinsic subtypes of breast cancer. Br J Cancer 2013; 108: 1480-7.

12. Rethemiotaki I, Rethemiotakis A. Stroke and breast cancer in the United States during 2007-2017. Arch Med Sci Atheroscler Dis 2019; 4: e134-40.

13. Lee KW, Bode AM, Dong Z. Molecular targets of phytochemicals for cancer prevention. Nature Rev Cancer 2011; 11: 211-8. 
14. Vallianou NG, Evangelopoulos A, Schizas N, Kazazis C. Potential anticancer properties and mechanisms of action of curcumin. Anticancer Res 2015; 35: 645-51.

15. Whitlock NC, Baek SJ. The anticancer effects of resveratrol: modulation of transcription factors. Nutrition Cancer 2012; 64: 493-502.

16. Rah B, Rasool Ru, Nayak D, et al. PAWR-mediated suppression of $B C L 2$ promotes switching of 3-azido withaferin A (3-AWA)-induced autophagy to apoptosis in prostate cancer cells. Autophagy 2015; 11: 314-31.

17. Eken MK, Ersoy GS, Kaygusuz El, et al. Etanercept pro tects ovarian reserve against ischemia/reperfusion injury in a rat model. Arch Med Sci 2019; 15: 1104-12.

18. Guo H, He Y, Bu C, Peng Z. Antitumor and apoptotic effects of 5-methoxypsoralen in U87MG human glioma cells and its effect on cell cycle, autophagy and PI3K/ Akt signaling pathway. Arch Med Sci 2019; 15: 1530-8.

19. Thaiparambil JT, Bender L, Ganesh T, et al. Withaferin A inhibits breast cancer invasion and metastasis at sub-cytotoxic doses by inducing vimentin disassembly and serine 56 phosphorylation. Int J Cancer 2011; 129: 2744-55.

20. Sabina EP, Indu H, Rasool M. Efficacy of boswellic acid on lysosomal acid hydrolases, lipid peroxidation and anti-oxidant status in gouty arthritic mice. Asian Pac Trop Biomed 2012; 2: 128-33.

21. Siddiqui M. Boswellia serrata, a potential antiinflammatory agent: an overview. Indian J Pharmaceut Sci 2011; 73: 255-61.

22. Park B, Sung B, Yadav VR, Cho SG, Liu M, Aggarwal BB. Acetyl-11-keto-beta-boswellic acid suppresses invasion of pancreatic cancer cells through the downregulation of CXCR4 chemokine receptor expression. Int J Cancer 2011; 129: 23-33.

23. Shen $\mathrm{Y}$, Takahashi M, Byun HM, et al. Boswellic acid in duces epigenetic alterations by modulating DNA meth ylation in colorectal cancer cells. Cancer Biol Ther 2012; 13: 542-52.

24. Glaser T, Winter S, Groscurth P, et al. Boswellic acids and malignant glioma: induction of apoptosis but no modulation of drug sensitivity. Br J Cancer 1999; 80: 756-65.

25. Zhao W, Entschladen F, Liu H, et al. Boswellic acid acetate induces differentiation and apoptosis in highly metastatic melanoma and fibrosarcoma cells. Cancer Detect Prev 2003; 27: 67-75.

26. Banno N, Akihisa T, Yasukawa K, et al. Anti-inflammatory activities of the triterpene acids from the resin of Boswellia carteri. J Ethnopharmacol 2006; 107: 249-53.

27. Rah B, Amin H, Yousuf K, et al. A novel MMP-2 inhibitor 3-azidowithaferin A (3-azidoWA) abrogates cancer cell invasion and angiogenesis by modulating extracellular Par-4. PLoS One 2012; 7: e44039.

28. Safayhi H, Mack T, Sabieraj J, Anazodo MI, Subramanian LR, Ammon H. Boswellic acids: novel, specific, nonredox inhibitors of 5-lipoxygenase. J Pharmacol Exp Ther 1992; 261: 1143-6.

29. Safayhi H, Sailer ER, Ammon H. Mechanism of 5-lipoxygenase inhibition by acetyl-11-keto-beta-boswellic acid Mol Pharmacol 1995; 47: 1212-6.

30. Bishayee A, Ahmed S, Brankov N, Perloff M. Triterpenoids as potential agents for the chemoprevention and therapy of breast cancer. Front Biosci 2011; 16: 980-96.

31. Poeckel D, Werz O. Boswellic acids: biological actions and molecular targets. Curr Med Chem 2006; 13: 3359-69.

32. Takahashi M, Sung B, Shen Y, et al. Boswellic acid exerts antitumor effects in colorectal cancer cells by modulat ing expression of the let-7 and miR-200 microRNA family. Carcinogenesis 2012; 33: 2441-9.

33. Li W, Liu J, Fu W, et al. 3-O-acetyl-11-keto-beta-boswellic acid exerts anti-tumor effects in glioblastoma by arresting cell cycle at G2/M phase. J Exp Clin Cancer Res 2018; 37: 132.

34. Patridge E, Gareiss P, Kinch MS, Hoyer D. An analysis of FDA-approved drugs: natural products and their derivatives. Drug Discov Today 2016; 21: 204-7.

35. Ding $Y$, Chen $M$, Wang $M$, et al. Neuroprotection by acetyl-11-keto-beta-boswellic acid, in ischemic brain injury involves the Nrf2/HO-1 defense pathway. Sci Rep 2014; 4: 7002.

36. Hartmann RM, Martins MIM, Tieppo J, Fillmann HS, Marroni NP. Effect of Boswellia serrata on antioxidant status in an experimental model of colitis rats induced by acetic acid. Dig Dis Sci 2012; 57: 2038-44.

37. Singh S, Khajuria A, Taneja S, Johri R, Singh J, Qazi G. Boswellic acids: a leukotriene inhibitor also effective through topical application in inflammatory disorders. Phytomedicine 2008; 15: 400-7.

38. Parr C, Ali AY. Boswellia frereana suppresses HGF-mediated breast cancer cell invasion and migration through inhibition of c-Met signalling. J Transl Med 2018; 16: 281.

39. Stetler-Stevenson WG, Aznavoorian S, Liotta LA. Tumor cell interactions with the extracellular matrix during invasion and metastasis. Ann Rev Cell Biol 1993; 9: 541-73.

40. Taraphdar AK, Roy M, Bhattacharya R. Natural products as inducers of apoptosis: implication for cancer therapy and prevention. Curr Sci 2001; 80: 1387-96.

41. Roy NK, Deka A, Bordoloi D, et al. The potential role of boswellic acids in cancer prevention and treatment. Cancer Lett 2016; 377: 74-86.

42. Shukla S, MacLennan GT, Hartman DJ, Fu P, Resnick MI, Gupta S. Activation of PI3K Akt signaling pathway promotes prostate cancer cell invasion. Int J Cancer 2007; 121: 1424-32.

43. Singh I, Amin H, Rah B, Goswami A. Targeting EGFR and IGF 1R: a promising combination therapy for metastatic cancer. Front Biosci (Schol Ed) 2013; 5: 231-46. 